NEWS

\title{
Time running out for climate talks
}

\section{Rift between developed and developing nations might be too great.}

With just five negotiating days left before the global-warming summit in Copenhagen this December, the international climate community has tempered its expectations and begun to look for a graceful exit.

Pressure on global leaders has been building since negotiators signed the 'Bali Road Map' in December 2007, which set an aggressive timetable that was supposed to conclude in Denmark with a treaty to follow the 1997 Kyoto Protocol. Rich and poor countries alike have spent two years crafting climate policies and proposals, but deep divisions remain.

When irate representatives of developing nations walked out of a meeting with European officials in Bangkok earlier this month, many realized that even technical questions about how to structure a deal might be out of reach this year. Only one interim negotiating meeting remains - in Barcelona, Spain, on 2-6 November. Even staunch optimists are now rethinking their definition of success in Copenhagen.

"I don't like the term 'global deal', says Jennifer Morgan, who heads climate policy for the World Resources Institute in Washington DC. "The question is whether we can reach an agreement that allows countries to move forward with confidence."

Many ideas have been floated on how to accomplish that goal. Some argue for building a consensus around areas of agreement and holding off on contentious issues involving money or specific commitments to reduce greenhouse-gas emissions. Others focus on the architecture of a treaty and a broad, if symbolic, agreement among global leaders. Some have suggested simply 'stopping the clock' on negotiations for a few months.

Such proposals are intended to build political confidence and maintain momentum while allowing the United States more time to work out its domestic policy. Although the House of Representatives has passed climate legislation that would curb emissions to $17 \%$ below 2005 levels by 2020 and to $83 \%$ below by 2050 , Senate Democrats are running out of time to pass a companion bill before Copenhagen.

With the United States in limbo, the Europeans are necessarily leading the talks for the developed world. The European Union (EU) has committed to reduce its greenhouse-gas emissions by $20 \%$ below 1990 levels by 2020 and by $30 \%$ if there is a global deal, but even those numbers are not enough for most developing countries. The Group of 77 (G77), which represents China, India and the majority of developing nations, is calling on rich countries to cut their emissions by $40 \%$ by 2020 . So far, only Norway has stepped up to that challenge.

India's environment minister, Jairam Ramesh, says the negotiations are unlikely to go anywhere unless wealthy nations embrace more ambitious emissions reductions and promise more money to help developing countries cope with climate change. He says negotiators should focus on a few key issues, including deforestation, adaptation money for the least developed nations, and the Clean Development Mechanism, which allows rich countries to offset their emissions by paying for clean-energy and other 'green' projects in the developing world.

"We need a more limited and more pragmatic approach if we are going to make Copen-

At the same time, wealthy nations are insisting on stronger commitments from developing countries - many of whom have responded by introducing significant new policies. Indonesia recently announced plans to reduce its emissions by $26 \%$ by 2020 compared with predicted levels if emissions were left uncurbed, pledging a $41 \%$ reduction if it receives international aid for measures such hagen a success," Ramesh says.

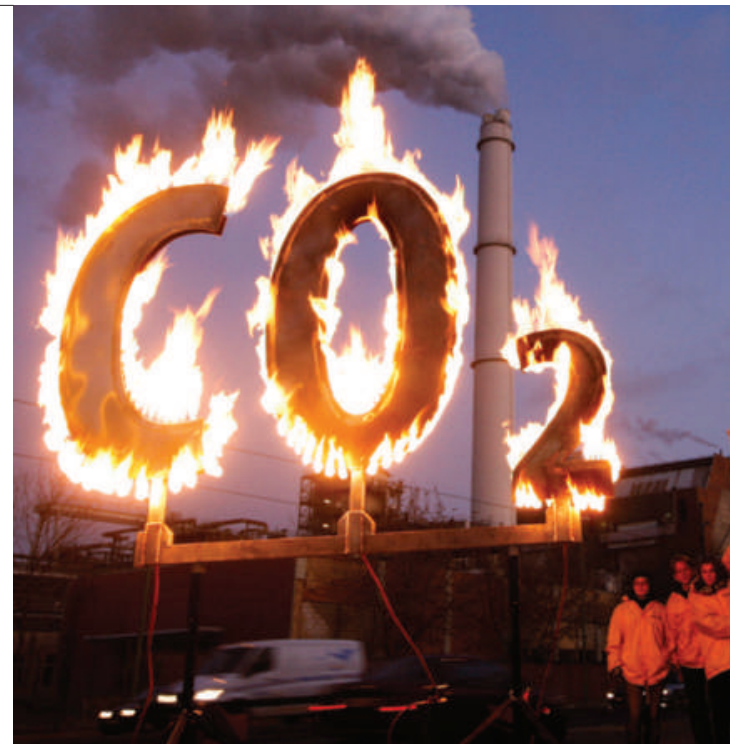

as stopping deforestation. Even India, which has repeatedly said it won't commit to anything until its per-capita emissions reach those of the developed world (see graphic), has proposed the idea of 'voluntary mitigation outcomes' that would allow the country to calculate specific emissions reductions based on expanding solar power and other existing climate policies.

China, the world's largest emitter, is moving forwards with aggressive energy-efficiency targets and renewable-energy mandates - but has yet to pledge binding commitments or agree a date to level off its explosive emissions growth.

Many were caught off guard in Bangkok when officials from the G77 and Europe fought over the future of the Kyoto Protocol. The G77 wants to maintain Kyoto - which is binding for developed but not developing countries on greenhouse-gas emissions - as the primary international framework. EU officials want to create a single new treaty under the original UN Framework Convention on Climate Change and then import the Kyoto Protocol. The United States claims neutrality, but some fear that it could impede progress by cherry-picking which parts of Kyoto it would

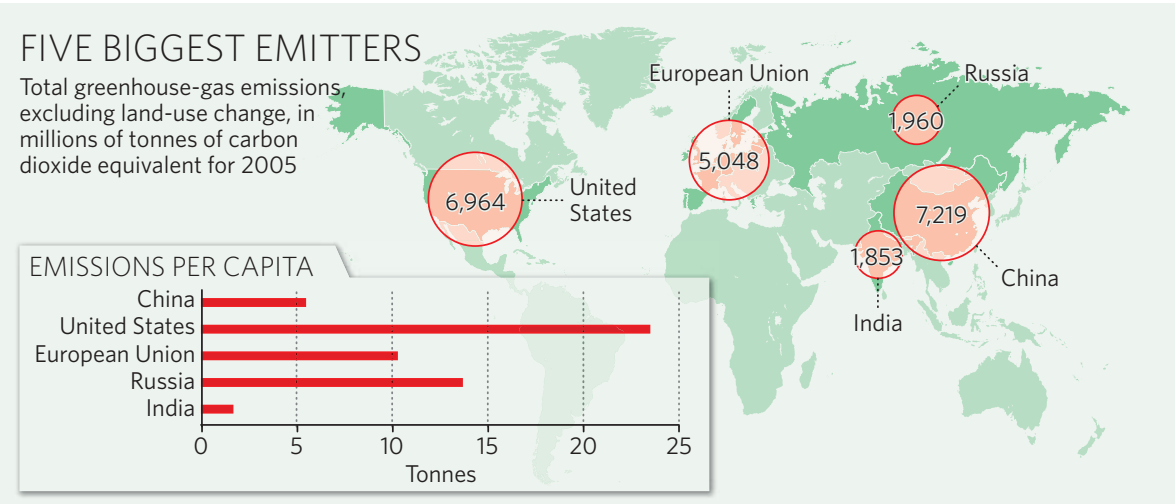




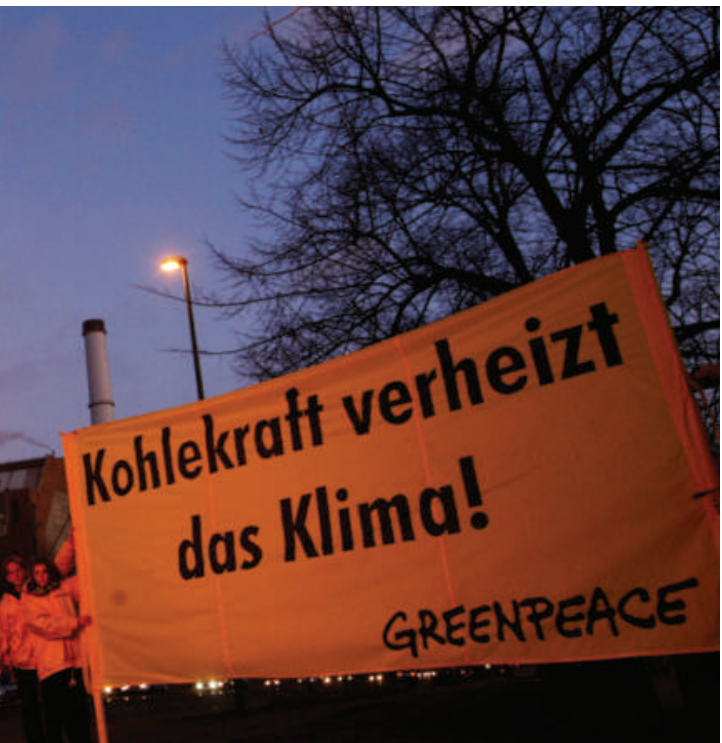

be willing to subscribe to in a new treaty.

Some observers believe that the biggest challenge will be money, particularly in the midst of an economic crisis. Costs for adaptation to climate change in the developing world alone have been estimated at US $\$ 100$ billion annually, and some suggest the figure could be two or three times that amount. The World Bank estimates that establishing a low-carbon economy in developing countries could cost several hundred billion dollars each year.

Money could enable progress on other fronts. Some developing nations have proposed to allow rich countries that cannot sufficiently reduce their emissions to make up the shortfall with cash. Indeed, after blasting the inadequacy of the US climate proposals, India's Ramesh smiles and acknowledges that a deal would be much more likely if the United States were to put, say, $\$ 200$ billion on the table.

Saleemul Huq, who tracks adaptation issues for the London-based International Institute for Environment and Development, says that developed countries will have two more chances to address the issue before Copenhagen (see also Nature doi:10.1038/ news.2009.1019; 2009). The EU finance ministers were scheduled to meet as Nature went to press, and a meeting of the G20 finance ministers is due in early November.

"One expects that they will come back with some kind of offer, and that would then unlock other issues in the negotiations," Huq says. "They will still be wrangling about the amounts, but at least they will go into the process of negotiating. Right now they are posturing, not negotiating." Jeff Tollefson

See Editorial, page 1027, and online at www.nature. com/roadtocopenhagen

\section{Hwang verdict imminent}

Despite his research being exposed as fraudulent and unethical almost four years ago, the career of South Korean cloner Woo Suk Hwang has thrived. He has established a research institute, laid claim to a set of human-cloning patents, received a scientific excellence award, published a handful of papers and entered into a collaboration with a powerful provincial government.

Now Hwang faces his biggest hurdle yet: the possibility of jail time. As Nature went to press, a verdict was expected on charges that he knowingly used faked research results to apply for grants, embezzled as much as 2.8 billion Korean won (US\$2.4 million), and purchased human eggs in violation of the country's bioethics law.

The charges relate to two papers in which Hwang claimed to have created stem-cell lines from cloned human embryos, and to have used the technology to develop patient-specific stem cells (W. S. Hwang et al. Science 303, 1669-1674; 2004; and W. S. Hwang et al. Science 308, 1777-1783; 2005).

Both were found to have been fabricated.

In August, at the last of 43 judicial hearings on the affair, prosecutors sought four years in prison for Hwang. It was the end of an epic 40-month trial that saw the chief judge change three times, heard testimonies from more than 60 witnesses and included some bizarre moments such as when Hwang claimed he could not account for some of his funding because he had used it to pay Russian mafia for access to the DNA of a frozen mammoth that he hoped to clone.

Hwang still has powerful supporters. In June, he received an award from the Jang Yeong-sil Memorial Foundation for scientific excellence. In August, the South Korean province of Gyeonggi announced that it planned a collaboration with Hwang to develop transgenic animals able to grow organs for transplantation to humans. And on 12 October, 33 parliamentarians submitted a petition to the Seoul Central District Court Criminal Division pleading for leniency in sentencing Hwang so that he can continue his research without further ado.

Meanwhile, stem-cell science in South Korea has also bounced back from the scandal. In July, the government promised to triple its funding for the field to 120 billion won by 2015 . The government is also putting together a plan to give about 20 top stem-cell projects up to 1 billion won each over two years, with the possibility of twice that amount in a subsequent funding round. In April, the government approved an application by Seoul's Pochon CHA University to carry out human therapeutic cloning experiments.

"The future of stem-cell research is very promising," says Dong-Youn Hwang of the Pochon CHA University. "Many Korean people now realize that stemcell-based therapy is not magic, but only results from hard work, huge investment and continuous support," he adds.

Developmental biologist Kunsoo Rhee of Seoul National University, where Woo Suk Hwang worked until he was dismissed in 2006, says that the increased attention on scientific conduct has had some positive outcomes, including an undergraduate course on misconduct, which began at the university two years ago. "If we have something like [the Hwang case] all the time it would be bad, but once every 10 years - or hopefully only once in our lifetime - it can be a learning experience."

"After Hwang's scandal, Korean biotech is getting more transparent," adds Kyung-Sun Kang of Seoul National University's Adult Stem Cell Research Center. Kang says that although research on embryonic stem cells was difficult for a while, there has been an upsurge in the commercialization of adult stem cells, with several stem-cell therapies now in clinical trials.

If Woo Suk Hwang avoids a prison sentence, he says that he plans to continue his efforts to benefit South Korea by continuing his research on mammalian cloning, and still hopes to vindicate his human-cloning technique.

David Cyranoski 